\title{
Almanya'daki Türklerin Göç ve Entegrasyon Süreci: Birinci ve Üçüncü Kuşak Karşılaştırması
}

\author{
Hülya Demirağ ${ }^{1}$
}

\author{
Can Kakışım²
}

\section{Öz}

Göç olgusu, sosyal bilim alanlarında üzerinde sıklıkla inceleme yapılan konulardan biridir. 1961 yılından itibaren işgücü olarak Almanya'ya giden Türk göçmenlerin entegrasyon süreci göç araştırmalarında önemli yer tutmaktadır. Bu çalışma Almanya'ya işç olarak giden ve orada "misafir işçi” konumundan çıkıp kalııı olarak yerleşen Türk göçmenlerin kültürleşme, entegrasyon ve asimilasyon süreçlerini kuşaklararası karşılaştırmalı olarak incelemektedir. Bu bağlamda birinci kuşak ve üçüncü kuşak göçmenlerin aralarındaki farklılıklar ele alınmakta ve iki kuşak arasındaki çatş̧ma ve Alman toplumuna entegre olma süreçleri üzerinde durulmaktadır. Böylece Almanya'daki Türkiye kökenli göçmenlerin Türk kimliğini ve kültürünü devam ettirme düzeyleri kuşaklar arasında mukayese edilmekte ve Alman kültürünü benimseme düzeylerinde etkili olan faktörler ele alınmaktadır. Ayrıca makalede, Alman devletinin uyguladığı entegrasyon politikalarının amacı, etkinlik düzeyi ve özellikle üçüncü kuşak göçmenler üzerindeki etkisi de tespit edilmeye çalışılmaktadır. Bu amaçlar çerçevesinde çalışma konuyla ilgili klasik ve güncel eserleri kapsayan geniş bir literatür taraması sunmaktadır.

Anahtar Kelimeler

Göç • Misafir iş̧̧i • Entegrasyon • Asimilasyon • Kuşaklararası farklılık

1 Sorumlu Yazar: Hülya Demirağ (Arş. Gör.), Karabük Üniversitesi, Uluslararası Politik Ekonomi Yüksek Lisans Programı, Karabük, Türkiye. E:posta: hulyademirag4@gmail.com

2 Can Kakışım (Dr. Öğr. Üyesi), Karabük Üniversitesi, İktisadi ve İdari Bilimler Fakültesi, Uluslararası İlişkiler Bölümü, Karabük, Türkiye. E-posta: cankakisim@karabuk.edu.tr

Atıf: Demirağ, H. ve Kakışım, C. (2018) Almanya'daki Türklerin göç ve entegrasyon süreci: Birinci ve üçüncü kuşak karşılaştırması. Sosyal Siyaset Konferansları Dergisi, 75, 123-152. http://dx.doi.org/10.26650/jspc.2018.75.0011 


\title{
Process of Migration and Integration of Turks in Germany: Comparison of the First and Third Generations
}

\author{
Hülya Demirağ ${ }^{1}$ (1) \\ Can Kakışım²
}

\begin{abstract}
The concept of migration is one of those subjects which are frequently examined in the fields of social sciences. Turkish immigrants who have moved to Germany beginning from 1961 as guest workers hold a crucial place in migration studies. This study investigates the processes of culturalization, integration, and assimilation of Turkish immigrants who came to Germany as guest workers and eventually settled there permanently. In this sense, differences between the first and third generations of immigrants are examined, and their process of integration with German society is analyzed. In this way, Turkish immigrants' level of adoption of Turkish identity and preserving Turkish culture is investigated among the generations, and the factors that became influential in their adoption of German culture are analyzed. Furthermore, the aim of German integration policies, their level of efficiency, and their influence-especially on third-generation immigrants-are discussed in the article. In line with this purpose, the study presents a broad literature review comprising both classical and contemporary works.
\end{abstract}

\section{Keywords}

Migration • Guest worker • Integration • Assimilation • Difference between generations

1 Corresponding author: Hülya Demirağ (Ress. Assist.), Karabuk University, Master's Program in International Political Economy, Karabuk, Turkey. Email: hulyademirag4@gmail.com

2 Can Kakışım (Dr. Lecturer), Karabuk University, Faculty of Economics and Administrative Sciences, Department of International Relations, Karabuk, Turkey. Email: cankakisim@karabuk.edu.tr

To cite this article: Demirağ, H. \& Kakışım C. (2018). Process of migration of Turks in Germany: Comparison of the first and third generations. Sosyal Siyaset Konferans/arı Dergisi, 75, 123-152. http://dx.doi.org/10.26650/jspc.2018.75.0011 


\section{Extended Summary}

After the Second World War, European states attempted to overcome major economic difficulties by inviting guest workers to their countries in order to resolve the manpower deficit left by the war. Over time, however, immigrants who moved from developing countries like Turkey to Western European states abandoned their "guest worker" status and began to settle permanently in these countries. Because of this, immigrants' cultural problems, identity issues and concepts of culturalization, integration, and assimilation began to be studied to a much greater extent in the fields of sociology and political science.

Turkish labor migration to Germany started following an agreement signed between Turkey and Germany on October 30, 1961. In the first year, 6,800 Turks arrived in Germany, and their population steadily increased over the years. The Turkish population in Germany rose to 652,000 in $1971,1,546,000$ in 1981, and 1,780,000 in 1991. Turks who moved to Germany in the first decade following the agreement are considered to be the first generation of Turkish immigrants. Members of this generation had no information about Germany before their arrival and experienced serious difficulties in adapting to their new country. They were generally unskilled workers, they could not speak German, and they preserved Turkish values rather than assimilating German ones. As this group was seen by the Germans as temporary guest workers, integration policies were not applied to them

The second generation of Turkish immigrants in Germany appeared from 1974 to 1984 . They were the children of the first generation, or they came to Germany under the laws of family reunification. In fact, beginning from the 1980s, the German government sought certain ways to encourage Turkish immigrants to return to their country, but these efforts proved largely ineffective. Even if a number of Turkish immigrants returned to Turkey, their children opted to stay in Germany, and thus the Turkish population continued to increase. Members of the second generation could speak some German, and some of them were educated in German schools. Following the formation of the second generation, German officials realized that presence of Turks in Germany would be permanent, and accordingly initiated some policies to ensure the integration of next generations to German society.

The third generation of Turkish immigrants is the product of these policies. These people are young, aged 18-29, and living in Germany. Compared to the previous generations, members of the third generation have a much closer relationship to German society. They were born and educated in Germany, they can speak German fluently and their friends are generally German. As they have also adapted to German culture and lifestyle to a great extent, it can be argued that the integration 
policies launched by the German state took root in this generation. Because of their proximity to German language and culture, these young Turks are quite active in the daily and professional life of Germany. On the other hand, they have not learned Turkish language and culture very well; they have some persistent conflicts with their families and previous generations. Alienation from Turkish identity is the most crucial problem in the overall structure of third generation.

In this study, the process of migration and integration of Turkish immigrants in Germany is examined and a comparison of the first and third generation Turks is made. The article argues that the changing cultural dimension of the Turkish immigrants in Germany originated from state policies to bring third-generation Turks closer to German culture and society. 


\section{Almanya'daki Türklerin Göç ve Entegrasyon Süreci: Birinci ve Üçüncü Kuşak Karşılaştırması}

İkinci Dünya Savaşı'ndan büyük yıkımla çıkan Avrupa ülkeleri ve özellikle Almanya, bu kayıpların etkisini azaltmak ve ekonomik gelişimin devamını sağlamak adına savaş sonrasında birtakım adımlar atmış ve savaştan kaynaklanan işgücü açığını karşılamak için birçok ülkeyle anlaşmalar yaparak "geçici işçi”" alımına başlamışlardır (Chin, 2007: 33). Gerçekleşen bu işçi göçleriyle birlikte "göç" kavramı sosyoloji ve siyaset bilimi alanlarında eskiye nazaran daha yoğun bir biçimde inceleme altına alınmıştır.

Göç alanındaki çalışmalarda, uluslararası işgücü göçüne yönelik olarak birbirinden oldukça farklı teoriler geliştirilmiştir. Fakat kuramsal açıdan uluslararası işgücü akımının klasik olarak iki genel bakış açısı çerçevesinde çözümlenmeye çalışıldığ1 görülmektedir. Bunların birincisi, modernleşme kuramı ile birlikte anlam bulan Dengeli Büyüme Modeli, ikincisi ise işgücü alan merkez ülkelerle bu ülkelere işgücü veren çevre ülkeler arasındaki ilişkilere odaklanan Merkez-Çevre Kuramıdır (Gitmez, 1983: s. 81). Ancak İkinci Dünya Savaşı'ndan sonra göç olgusunun inceleme alanında belirli değişiklikler olmuş ve zamanla bu iki kuramın yanı sıra göçmenlerin sorunları, kimlik sorunsalı, eğitim meseleleri, kültürleşme, entegrasyon ve asimilasyon gibi konulara değinen yaklaşımlar göç çalışmalarında daha sık yer bulmaya başlamıştır. Göç çalışmalarında gerçekleşen bu değişimin önemli bir sebebi, aralarında Türkiye gibi gelişmekte olan birçok ülkeden Avrupa ülkelerine giden işçilerin başlangıçta "misafir işçi” konumunda iken sonrasında geçicilik durumlarının değişmesi ve bulundukları ülkelerde kalıı bir nitelik kazanmaları olmuştur.

Göçün süreklilik kazanması üzerine Avrupa ülkeleri göç alımına belirli s1nırlamalar getirmeye yönelmiş, ancak bu sınırlamalar bile göçmen işçilerin gelişini engellemekte yetersiz kalmıştır (Şahin, 2010: s. 104). Göçmen işçilerin çok az bir kısmı ülkelerine dönme kararı almış, geri kalan büyük çoğunluk ise geçici olarak geldikleri ülkelerden ayrılmak yerine, yanlarına ailelerini de almayı tercih etmişlerdir. Almanya başta olmak üzere göçmen alan Avrupa ülkeleri bu durum karşısında ortaya çıkan sorunların çözümüne yönelik birtakım stratejiler geliştirmişlerdir. ABD'de uygulanan "eritme potası” modeli baz alınarak öncelikle "asimilasyon", daha sonrasında ise bunu yumuşatma yoluna gidilerek "adaptasyon" ve en son olarak da iki farklı kültürün bir arada bütünleşmesini sağlamak adına "entegrasyon” gibi politikalar ortaya konul- 
muştur. Çokkültürlülük üzerine yoğunlaşan çalışmalar ise 1990'lı yıllardan sonra söz konusu olmaya başlayacaktır (Şahin, 2012: s. 228).

Bu çalışmada, Almanya'da yaşayan Türk göçmenlerin göç ve entegrasyon süreçleri ele alınırken; birinci ve üçüncü kuşak Türk göçmenlerin karşılaştırılması yapılmaktadır. Çalışmada Birsen Şahin'in (2010) Hartmut Esser'in teorisine eleştirel bir bakışla iddia ettiğgi, Almanya'nın kendisi için bir potansiyel olarak gördügü üçüncü ve sonraki kuşak göçmenler üzerinde yürüttüğü entegrasyon politikalarının bu kitlenin kimlik ve aidiyet duyguları üzerinde etkili olduğu ve bu etkinin entegrasyondan ziyade asimilasyonu hedeflediği düşüncesi temel alınmıştır. Zira yapılan çalışmalarda Almanya'daki Türk göçmenlerde zamanla kuşaklararası farklılıklar görülmeye başlanmıştır. En büyük fark ise birinci ve üçüncü kuşak arasında görülmektedir.

Ele alınan konunun değerlendirilmesini kolaylaştırmak için makalede ilk olarak göç, entegrasyon ve asimilasyon kavramları üzerine durulacak, hemen ardından Türklerin Almanya'ya uzanan göç süreci ve kuşakların oluşumu incelenecektir. Daha sonra ise Almanya'daki Türk göçmenler, farklı kuşaklar bağlamında ele alınırken özellikle birinci ve üçüncü kuşaklar karşılaştırmalı olarak analiz edilecektir. Ancak burada unutulmaması gereken bu çalışmanın temsili bir çalışma olmadığı, sadece ulaşılabilen güncel araştırmalar üzerinden bir karşılaştırma yaptığ 1 ve bu çalışmalar ve bunların karşılaştırmasının Almanya'daki Türklerin hepsine genellenemeyeceğidir. Çalışma bir genelleme yapma amacında değil, ulaşılabilen kaynaklar üzerinden, sadece kullanılan çalışmalara ilişkin bir değerlendirme yapma amacındadır.

Çalışmanın kapsamının belirlenmesi için konuyla ilgili geniş bir literatür taraması yapılmıştır. Bu kapsamda makalede kullanılacak kaynaklar göç konusunda yazılan kaynaklar içinden "göç, asimilasyon ve entegrasyon" meseleleri üzerine odaklanma kriteri bağlamında seçilmiştir. Almanya'daki Türk göçmenlerin analizi ile ilgili olarak ise ilgili literatürdeki en güncel Türkçe ve İngilizce kaynaklar araştırmada analiz edilecek kaynaklar olarak belirlenmiştir. Bu bağlamda Adıgüzel (2011), Aksoy (2010), Algan, Bisim ve Verdier (2011), Başkurt (2009), Bedirhan (2009), Benhabib (2009), Bilgin (2007), Canatan (1990), Chin (2007), Dempsey (2013), Esser (2000), Gitmez (1983), Gorlach (2015), Gökçe (2006), Gülboy (2015), Haksever (2014), Kakışım (2018), Kartari (2006), Kırmızı (2016), Kılıç ve Menjivar (2013), 
King ve Kilınç (2014), Kümbetoğlu (2003), Mueller (2006), Mutluer (2003), Öztürk (2011), Park ve Burgess (1969), Perşembe (2005), Stowasser (2002), Birsen Şahin (2010, 2012) Veysel Şahin (2013), Şen (2010), Toksöz (2006), Tol (2012), Wittle (2018), Yalçın (2002), Yeşilyaprak (1989) ve Yurdakul'un (2018) eserleri ile Göç Terimleri Sözlügü (2009) ile Sosyal Bilimler Ansiklopedisi (1988) ve Birleşmiş Milletler Sosyal Kalkınma Araştırmaları Enstitüsü'nün (UNRISD) araştırılan konuyla alakalı 1994 tarihli raporu kullanılmıştır. Makale için saha çalışması yapma imkanının olmamasından dolayı, var olan kaynaklar arasından makalenin amacına uygun olan çalışmalar değerlendirilmiş ve bunlar mukayeseli biçimde ele alınmıştır.

\section{Çalışmanın Teorik Arkaplanı: Göç, Entegrasyon ve Asimilasyon}

\section{Göç}

Göç kavramı; insanların doğal, iktisadi, siyasal ve sosyal sebeplerden dolayı devamlı olarak yaşadıkları yerden başka bir yere toplu veya bireysel olarak hareket etmeleri ve oraya yerleşmeleri olarak ifade edilmektedir. Dolayısıyla, kavram genel anlamda bir mekândan diğer bir mekâna doğru hareketliliği göstermektedir. Göç, yaşanılan bölgenin kalıcı veya geçici şekilde değiştirilmesi ya da başka bir bölgede başka bir yönetimin idaresi altına girmek şeklinde anlaşılmaktadır. Bununla beraber devlet sınırları içi ya da arasında gerçekleştirilen değişiklikler iç göç ve dış göç farklılığını da ortaya çıkarmıştır (Haksever, 2014: s. 6). Aynı toprak sınırları içerisinde yapılan hareketliliğe "iç göç" denilirken; toprak sınırları dışına yani başka ülkelere yapılan yer değiş̧ikliği ise "dış göç" veya "uluslararası göç" olarak tanımlanmaktadır. Göç eylemini gerçekleştiren kişiye ise "göçmen" ismi verilmektedir (Göç Terimleri Sözlüğü, 2009: s. 16).

Göç, toplumsal değişimin ortaya çıkardığı kolektif bir eylem olduğu gibi göç alan ve göç veren ülkedeki toplumun bütününe yansır. Bununla beraber, göç ve başka bir ülkede hayat sürdürme deneyimi kazanmak gerçekte yer alan planların değişmesinde etkili olabilmektedir. Göçmenlerin vatanlarını geride bıraktıkları dönemdeki düşünceleri gittikleri ülkedeki kaldıkları süreç içerisinde zaman zaman değişiklik göstermektedir. Devlet göç aracılığıyla etnik bakımdan farklılaşmış bir toplum yapısı inşa etmek amacıyla yola çıkmasa da politik uygulamalar ve toplumsal ilişkiler, farklı ulusal kimlikler ve etnik azınlıkların oluşumuna neden olmaktadır (Aksoy, 2010: s. 17). 
Göç hareketleri insanlık tarihi kadar eskiye dayanmaktadır. İnsanlar yaşamları süresince çeşitli nedenlerle bulundukları yerden başka bölgelere göç etmiş veya göç etmeye zorunlu bırakılmışlardır. Tarihsel süreçte modern anlamda ilk kitlesel göç hareketleri Amerika kıtasının keşfedilmesinden sonra görülmüştür. Bu keşiften sonraki göç hareketinde çok sayıda insan Avrupa'dan Amerika'ya gitmiştir. İspanya ve Portekiz'den başlatılan bu göç dalgası zamanla hız kazanarak diğer Avrupa devletlerine de yayılmıştır. İlk modern kitlesel göçler ekonomik sorunlardan kaynaklı olarak gerçekleşmiştir. Göç hareketleri daha sonraki süreçte esir ticaretleriyle yeni bir boyut kazanacaktır (Mutluer, 2003: s. 30). Toksöz'e göre ise fetihler ve sömürgeleştirme faaliyetleri, 16. yüzyılda keşfedilmiş olan yeni kaynaklarda çalıştırılma amacıyla kullanılacak kölelere gereksinim duyulması ve Batı Avrupa ve sömürgeleştirilen ülkeler arasındaki ilişkiler ile birlikte göçü tetiklemiştir. Batı'daki sanayileşme hareketi ile ekonomik sebeplerle gerçekleşen göçler 19. yüzyılda da artmaya devam etmiş, Birinci Dünya Savaşı'nın sonrasında ise ucuz işgücüne gereksinim duyulmuştur (2006: s. 11). Uluslararası nüfus hareketlerinin, önemli ölçüde sanayileşme ile birlikte başladığı ve bugüne kadar da devam ettiği belirtilmelidir. Sömürge kaynaklar1na sahip olan gelişmiş ülkeler, azgelişmiş ülkelerden göç almışlardır. Gelişmiş ülkelerin sanayileşmeyle birlikte ortaya çıan işgücüne olan ihtiyacı işgücü göçünün gerçekleşmesini sağlamıştır (Öztürk, 2011: s. 6).

1960’lı yı1larda ise Avrupa' da yeni bir göç dalgası başlamıştır. İkinci Dünya Savaşı'nın ardından Batı Avrupa'da yaşanan ekonomik gelişim süreci, İtalya ve Yugoslavya gibi ülkelerden göçmen alan Avrupa devletlerinin bilhassa da Almanya'nın göç sahalarının genişlemesine neden olmuştur. Türkiye, Filistin, İspanya, Mısır, Yunanistan gibi birtakım ülkeden binlerce vatandaş en başta Almanya olmak üzere sanayileşmiş Avrupa ülkelerine göç etmiştir (Mutluer, 2003: s. 32).

Ekonomi alanında gerçekleşen atılımlar, ucuz işgücüne duyulan ihtiyaç ve bu ihtiyacın diğer ülkelerden karşılanması bazı kültürel, toplumsal ve siyasi sorunları da beraberinde getirmektedir. Bazı devletler göçü kısıtlama yoluna giderken bazıları da belirli derecelerde kültürel çoğulculuğu benimsemişlerdir. Göçlerle birlikte homojen ulus-devlet yapıları değişime uğrarken, bu durum Avrupalı devletlerin yeni politikalar oluşturmasına sebep olmuştur (Haksever, 2014: s. 5). 
Aynı zamanda, uluslararası göç ile dil, din, kültür ve gelenek bakımından birbirinden farklı olan bireyler aynı ortamda hayatlarını devam ettirmeye mecbur kalmaktadır. Bu durum ise birtakım iletişim ve adaptasyon problemlerini oluşturmakta ve daha büyük sorunlara sebep olabilmektedir. Zira insanların doğdukları topraklarından ayrılıp başka devletlere göç etmesi ekonomik sonuçlardan ziyade siyasal ve sosyal sonuçlar doğurmuştur. Göçmenler bir müddet sonra kültürel kimliklerini irdelemeye başlamış ve içinde yaşadıkları sosyal çevreye karşı bazı reaksiyonlar göstermişlerdir. Gidilen ülkelerin farklı kültürel ve sosyal realiteleri göçmen bireylere bambaşka kolektif kimlikler yüklemiştir (Kümbetoğlu, 2003: s. 271).

\section{Entegrasyon ve Asimilasyon}

Entegrasyon kelimesi, Alman literatüründe bir bütünü tekrardan oluşturma ya da inşa etme olarak ifade edilmektedir. Türk literatüründe ise bir bütünün parçaları arasındaki uygunluk, ahenk anlamına gelmektedir (Haksever, 2014: s. 20). Uluslararası Göç Örgütü (IOM) tarafından hazırlanmış olan Göç Terimleri Sözlügü’nde entegrasyon kavramı, göçmenleri hem bireysel hem de grupsal olarak toplumun bir üyesi kabul eden süreç olarak belirtilmiştir. Buna göre, göç alan devletlerin göçmen kabulü için aradıkları nitelikler ülkelere göre değişiklik göstermektedir ve entegrasyonun sorumluluğu tek bir gruba ait değildir. Hem göçmenler hem de ev sahibi olan devlet, kurumlar ve toplumlar entegrasyondan mesuldür (Göç Terimleri Sözlüğü, 2009: s. 17). Bu konuyla ilgili birçok eseri bulunan sosyolog Friedrich Heckmann ise entegrasyonu şu şekilde özetlemektedir; "Genel anlamda entegrasyon yeni bir toplumsal grubun mevcut sosyal yapılar ile topluma kazandırllmalart, ayrica bu süreçte nasıl ve ne şekilde hazırdaki grubun sosyo-ekonomik, yasal ve kültürel ilişkilerine dahil edileceğini ifade eder" (Haksever, 2014: s. 22).

Entegrasyon olgusuyla ilgili çalışmaların gelişiminde göçlerin artarak devamı önemli rol oynamıştır. Zira Avrupa ülkeleri göç alımına birtakım kısıtlamalar getirmişse de bu kısıtlamalar göçmen işçilerin gelmesini önlemede yeterli olmamıştır. Göç eden işçiler gerek aile birleşimi yoluyla gerekse de yasadışı farklı yollara başvurarak (kaçak girmek gibi) Avrupa'ya göç etmeye devam etmişlerdir (Şahin, 2010: s. 104). Göçmenlerin çok az bir kısmı kendi ülkelerine geri dönmüş, göçmenlerin büyük çoğunluğu ise bulundukları ülkelerden ayrıl- 
mamış, bunun yerine eşlerini ve çocuklarını da yanlarına getirerek; böylece bir gün ülkelerine dönme fikriyle gelmelerine rağmen artık ailelerinin de yanlarında olmasından dolayı, bu ülkelerde kalıcı olmuşlardır. Onlar için yerleştikleri bu ülkeler ikinci bir memleket haline dönüşmüştür ve "Aile birleşmesi göçmen işçilerin oraya yerleşmelerinde dönüm noktası” olmuştur (Toksöz 2006: s. 31). $\mathrm{Bu}$ durumu aldıkları vatandaşlıklarla ve sahip oldukları mülklerle de sağlamlaştıran göçmenlerin artık geçici olmadıklarının anlaşılması üzerine gerek sosyologlar gerek ekonomistler gerek siyaset bilimciler gerekse de psikologlar için göç olgusunun araştırılacak ve üzerinde çalışılacak bir başka alanı olarak entegrasyon konusu ortaya çıkmıştır (Şahin, 2010: s. 104).

Göçmenlerin içinde bulundukları toplumda yaşadıkları sorunlar ve bulundukları ülkeyle bütünleşmeleri noktasında yapılan çalışmalarda, en başta göçmenlerin parçası oldukları topluma uyum sağlamaları anlamına gelen adaptasyon kavramı kullanılmıştır. Günümüzde ise göçmenlerin girdikleri yeni kültüre uyum sağlamalarının yanında etnik kültürlerini de korumaları ve devam ettirmeleri anlamına gelen entegrasyon kavramı tercih edilmektedir. Çünkü aynı ülke toprakları içinde bulunan bu kültürel gruplar ile kurulan iletişim de kültürlerarası bir özellik taşımaktadır (Kartari, 2006: s. 12). Bu durumda, göçmenler başka kültürlerin içerisinde hem kendi değerlerini korumak hem de yeni toplumla bir arada yaşamak istediklerinde bunu sağlayabilmek için entegrasyon gerekli bir yol olarak göze çarpmaktadır (Bilgin, 2007: s. 265).

Küreselleşme döneminde entegrasyon arayışı, ifadesini çağdaş çokkültürlülük projelerinde bulacaktır. Çokkültürlü yapıda göçmenler toplumun edilgen bir parçası olmak yerine kendi kimliklerini oluşturmak noktasında aktif olarak eylem içinde bulunmakta, devlet de bu girişimlere ortak yaşam ilkesi çerçevesinde destek vermektedir (Algan et al., 2012: s. 6). Bu anlamda çokkültürlülük azınlık grupların hem kültürel farklılıklarını korumaları hem de bu farklılıklarıyla birlikte toplumsal yapıda eşit bir yer bulmalarına dayanan bir vizyon olarak kendisini göstermektedir. Bu yaklaşımda, devletler yurttaşlarına sadece eşit haklar tanımakla kalmayacak aynı zamanda onların kimliklerini baskı altına almaktan da kaçınacaktır (Kakışım, 2018: s. 63)

O halde entegrasyon, farklı kültürel değerlere sahip insanların bu farkl1lıklarını koruyarak ve içinde bulundukları diğer kültürden de etkilenerek bir bütünlük içerisinde yaşamalarıdır. Entegrasyon ile bir ülke içerisinde veya bir 
toplumda kültürel dengenin sağlanması amaçlanmaktadır. Entegrasyon farklı değerlerin ortak noktalarını bir araya getirmeyi ve aynı toplumda hoşgörü içerisinde yaşamayı sağlamaktadır. Entegrasyon kavramını ilk kez kullanan Robert E. Park ve Ernest Burgess bunu asimilasyon olgusunu eleştirerek geliştirmişlerdir. Park ve Burgess'in kullanımına göre entegrasyon, bir grubun diğer grup içinde erimesi değil, toplum içindeki insanların birbirlerini daha yakından tanıması, birbirlerinin deneyimlerine, duygu ve tavırlarına daha aşina hale gelmeleri ve böylece ortak bir kültürel yaşamda bir araya gelmeleridir (Park ve Burgess, 1969: s. 735). Toplum içindeki herhangi bir grupla bütünleşmeyi reddetmek, onu görmezden gelmek ya da bu grup mensuplarını toplum dâhilinde belirli hak ve imtiyazlardan mahrum birakmak ise "dışlama" (exclusion) olarak tarif edilmektedir. Bu özelliğiyle dışlama olgusu entegrasyonun tam karşısında bulunmaktadır (UNRISD, 1994: s. 5). Ancak bir dişlamayı içermese de belirli bir azınlık grubunun başka bir toplumsal grup içinde, çoğu zaman baskı yoluyla özgül kültürel özelliklerini yitirecek düzeyde absorbe edilmesi de entegrasyonun amaçlarına uzak düşmektedir. Zira eğer hâkim kültür diğer kültürü etkisi altına alıp, kendi kültürünü azınlık durumundaki kültüre empoze etmeye çalışırsa bu durumda asimilasyon olgusu gerçekleşmektedir.

Asimilasyon kavramı Latince "similis" (benzer) kelimesinden türetilmiş, Fransızca ve İngilizcede ortak olan bir terimdir. Sözlükteki anlamı bir şeyi değiştirme yoluyla kendine benzetme ya da bir şeyin değişerek başka bir şeye benzemesidir. Türkçe'ye "özümleme” ve "özümseme" diye çevrilse de bu kelimelerin sözcüğün Latince karşılığıyla pek ilişkisi bulunmadığı ifade edilmektedir (Haksever, 2014: s. 25). Asimilasyon kavramının sınırlarını tam olarak çizmek ve tarihsel gelişimi ile anlam bakımından kapsamını anlatabilmek oldukça zor bir iştir. Göç Terimleri Sözlüğü’nde asimilasyon kavramı, bir etnik veya toplumsal grubun, genellikle de azınlığın fazla olan gruba uyum sağlaması olarak açıklanmaktadır. Sözlükte asimilasyon, dil, örf, adet, gelenek, değer, tutum ve davranışlarda ve aidiyet duygusunda bir değişimin gerçekleşmesi şeklinde ifade edilmekte ve asimilasyon için kültürel uyumdan daha ileri giden bir durum yakıştırması yapılmaktadır (Göç Terimleri Sözlügü, 2009: s. 3).

Asimilasyon, biyoloji biliminde "içine almak", özümlemek, özümsemek tanımlarından yola çıkılarak, sosyolojide ise özellikle göç sosyolojisi alanında kullanılmıştır. Bu kavram, tam anlamıyla anlamak, özümsetmek (özüm- 
semek) gibi durumları ifade etmek için psikoloji ve sosyoloji alanlarına da aktarılmıştır (Haksever, 2014: s. 26). Bir organizmanın aldığı bir besini organik hale getirmesiyle kendine mal etmesine, özümseme denilmektedir. Bir besinin organizma yapısının içerisinde eriyerek onun organik yapısı ile bütünleşmesi veya ona benzemesine de özümsenme denilmektedir. Etnolojideki karşılığı ise şu şekilde ortaya konulmaktadır: Baskın bir topluluğun, başka bir grubu veya topluluğu yapısında eritmesi ve kendine benzetmesi. Sosyolojide ise bir toplumun kültürel açıdan kendisinden farklı olan bir topluma dönüşmesine özümsenme; bir toplumun kültürel bakımdan kendisinden başka bir kültüre sahip olan toplumu kendi yapısına dönüştürmesi ve benzetmesine de özümseme denilmektedir (Sosyal Bilimler Ansiklopedisi, 1988).

Asimilasyonda aynı ülke içerisinde yaşayan farklı kültürler arasındaki birliğin devam ettirilebilmesi mümkün görülmediğinden aradaki farklılıkları ortadan kaldırabilmek için homojen bir toplum yaratma amacı öngörülmektedir (Gülboy, 2015: s. 57). Bu amaç ülkenin istikrarı ve güvenliği için zorunlu olarak görülebilmekte ve tek tipleştirme düşüncesiyle asimilasyoncu politikalar uygulanabilmektedir.

\section{Göç Literatüründe Almanya'daki Türk Göçmenlerde Kuşakların Oluşumuna İlişkin Veriler}

\section{Türkiye'den Almanya'ya Uzanan Göç}

Bir devletten diğer bir devlete doğru gerçekleşen hareket hali anlamına gelen uluslararası göç, hareket edenler ve geride kalanlar arasındaki bağları içerisinde barındıran, çok boyutlu siyasi, ekonomik ve kültürel bir süreci ifade etmektedir (Kartal ve Alptekin, 2015: s. 608). Uluslararası göç; insani müdahaleler, ulus-devletlerin vatandaşlarına karşı davranış ve tutumlarıyla ilgilendiği gibi, savaş suçları, insanlık suçları ve ulusal sınırlar içerisinde yaşayan insanlar ile ülke sınırları dışındaki yurttaşlar arasındaki ilişkileri de kapsamaktadır. (Benhabib, 2006: s. 20).

Farklı bölgeler arasında yaşanan kitlesel göçler yeni kentler ve devletlerin kurulmasına neden olmuştur. Bu göç hareketleri Amerika kıtasının keşfedilmesinden sonra deniz ötesi bir nitelik de kazanmıştır. 16. yüzyıldan itibaren Avrupa' dan birçok insan, yeni bir yaşam ümidiyle okyanus ötesinde bulunan 
yeni dünyaya göç etmiş ve oraya yerleşmiştir. Bu göç olaylarının gerçekleşmesinde ekonomik faktörler etkili olmuştur. Keşfedilen yeni kıtadaki büyük topraklarda tarım yapabilme olanağı ve okyanus aşırı ticaretin artması insanların kitlesel olarak buraya yerleşmelerinde önemli rol oynamıştır. 15. ve 18. yüzyıllar arasında Afrika'dan 15 milyon insanın köle olmaları için Amerika kıtasına taşındığı; 19. yüzyılda milyonlarca insanın Çin ve Hindistan'dan Amerika ve Avrupa'ya anlaşmalı işçi olarak gönderildiği; 20. yüzyılda yaşanan iki büyük dünya savaşının milyonlarca insanı vatanından ettiği bilinmektedir (Aksoy, 2012: s. 293). Göçün 20. yüzyıldaki genel sebeplerinin arasında en önemlisi ise kapitalizmin dünya çapındaki egemenliğidir. İkinci Dünya Savaşı'ndan sonra savaşa katılan devletlerin ekonomilerinde yaşanan sıkıntılar köy ve şehirlerde yaşamı zorlaştırmış ve kapitalist devletlerin işgücü ihtiyacında artışa neden olmuştur. Küreselleşmeyle birlikte giderek artan kitlesel ve bireysel göçler, konunun daha detaylı irdelenmesine sebebiyet vermiştir (Toksöz, 2006: s. 24).

Göç olgusu eskiden beri Türk tarihinin en belirgin özelliklerinden biri konumundadır. Zira Türk toplumu tarih sahnesine çıktığından beri göç hareketleriyle iç içe olmuştur ve Almanya'ya yönelik Türk göçü de bunun en son ve en kitlesel örneklerinden biridir. İkinci Dünya Savaşı'ndan sonra sanayisini büyük bir hızla geliştirme yoluna giden Almanya'da 1950'li yılların ortalarından itibaren işgücü açığı ortaya çıkmıştır. Bu açığı önce İtalya (1955), İspanya ve Yunanistan'dan getirdiği işçilerle karşılamaya çalışan Almanya, 1961'den itibaren Türkiye ve sadece maden ocaklarında çalıştırılmak üzere Fas’tan (1963) işçi göçü almaya başlamıştır ve alımlar sonraki yıllarda da devam etmiştir. Türk devletinin vatandaşlarını Almanya'ya gönderme noktasındaki temel amacı ise Türkiye'deki işsizliği azaltabilmek, giden işçilerin ülkelerine gönderecekleri dövizleri değerlendirmek ve geri geldiklerinde kazandıkları deneyim ve teknik bilgileri Türk sanayisine kazandırmaktır (Başkurt, 2009: s. 71).

30 Ekim 1961'de Almanya ve Türkiye arasında imzalanan "Türk İşçilerinin Almanya'ya Gönderilmesine Dair Anlaşma” kapsamında misafir işçi (Gastarbeiter) statüsü ile Almanya'ya gitmeye başlayan Türk vatandaşları, zaman geçtikçe misafir işçi konumundan çıkarak bu ülkeye yerleşmeye başlamışlardır. 1961 yılında Almanya sınırları içinde yer alan Türk göçmen sayı1 6.800 iken, bu say1 1971 y1lında 652.000'e ve 1981 y1lında 1.546.000'e 
yükselmiş, 1991 yılında ise 1.780.000'e ulaşmıştır (Aksoy, 2010: s. 8). Bu rakamlar modern dünya sisteminde, ABD'ye gerçekleşen Meksikalı göçünden sonraki en kitlesel göçün Türkiye'den Almanya'ya yönelik olarak vuku bulduğunu göstermektedir (King ve Kılınç, 2014: s. 126).

Zaman içerisinde Almanya'ya giden Türk işçilerin çoğunluğu bu uygulamanın belirli bir süre için ya da geçici olması düşüncesini terk ederek oraya yerleşmeyi tercih etmiş, işçilerden önemli bir bölümü kalıcı göçmen statüsüne geçmiştir. Bu yüzden ilk kuşak işçiler, bir süre sonra ailelerini de yanlarına alarak yaşamlarını Almanya'ya taşımışlardır. Bunun sonucunda ise ilk ve ikinci kuşaktan sonraki nesil hayat deneyimini Almanya'da kazanmış, sosyalleşme sürecini Almanya'da gerçekleştirmiş, sosyal yaşam alanı olarak Almanya'yı belirlemiş ve geleceğe yönelik planlarını bu devlet üzerine kurmuştur (Gökçe, 2006: s. 9).

Yaşamlarını yurtdışında sürdüren Türklerin büyük çoğunluğu Almanya'da bulunmaktadır. Almanya'da yaşayan 2,7 milyon Türk rakamsal açıdan Avrupa Birliği dışından gelen en büyük göçmen grubu ifade etmektedir. Günümüzde Almanya' da yaşayan Türk göçmenlerin yaklaşık olarak \%32'si Alman vatandaşlığına sahiptir. Genel nüfusun \%3,1'ine karşılık gelen Türk göçmenleri, on altı eyaletten oluşan Federal Almanya'nın dört eyaletinden, Bremen, Hamburg, Mecklenburg-Vorpommern ve Saksonya'dan daha fazla nüfusa sahiplerken, beş eyaletin Berlin, Brandenburg, Rheinland-Pfalz, SaksonyaAnhalt ve Schleswig-Holstein nüfuslarının yarısına yakın bir mevcuda denk düşmektedirler (Şen, 2010: s. 121).

Aslında 1961'den önce eğitim almak amacıyla Almanya'ya giden Türk gençleri olmuştur. Bu kişiler daha çok gelir durumu yüksek ailelerin çocukları olup Almanya'da ve diğer Avrupa ülkelerinde üniversite tahsili gördükten sonra Türkiye'de iyi iş imkânları bulmuşlardır. Fakat Almanya'daki Türkler denildiğinde akla ilk olarak öğrenim görmek için yurt dışına çıkmış olan gençler değil, çalışmak amacıyla Almanya'ya giden Türk işçiler gelmektedir. Almanya'ya Sirkeci Garı'ndan yola çıkan ilk Türkler Munih Garı'nın 11. Peronunda inmiştir, hatta bu perona 2011 y1lında Türkiye'den Almanya'ya göçün 50. y1lı anısına üzerinde "Kartoffel, ichliebedich" (Patates, seni seviyorum) yazılı bir anıt bile yapılmıştır. Bu anıt, Almanya'daki Türklerin bu ülkeyi artık geçici bir mekân değil kalıcı bir yer olarak kabul ettiklerinin göstergesi gibidir (Kırmızı, 2016: s. 146). 
Misafir işçi statüsüyle Almanya'ya giden Türkler, işverenlerin göçmen işçiler için hazırladıkları barakalar, eski atölyeler, bodrum katları, depolar ve apartman biçimindeki yurtlarda barınmak durumunda kalmışlardır. Avrupa standartlarına ve yönetmeliklere rağmen düşük kalitede ve sağlı açısından uygunsuz ortamlarda yaşamak durumunda bırakılmışlardır. Türk işçiler, imzaladıkları sözleşmede yer almamasına rağmen çoğunlukla maden ve taş ocaklarında, asbest ve lastik işlemede, demir-çelik ve metal sanayinde, plastik madde ve inşaat sektöründe, kiremit ve tuğla fabrikalarında, tekstil ve otomotiv sanayi gibi genellikle Almanların çalışmak istemedikleri ağır iş sahalarında çalıştırılmışlardır. Gürültülü, aşırı sıcak ve pis kokulu ortamlarda çalışmak zorunda bırakılmış, ancak kısa sürede çok para kazanmak istedikleri için bu tür zorluklara katlanmışlardır. Dil bilmediklerinden imzaladıkları sözleşmelerin içeriği hakkında bilgi sahibi olamamaları da durumlarını zorlaştıran diğer bir unsurdur. Bu durum, işçilerin büyük çoğunluğunda psikolojik sorunlara yol açarken, bazı işçiler de iş kazalarında hayatını kaybetmiştir (Perşembe, 2005: s. 16).

Türk işçiler Almanya'da kaldıkları süreçte para kazanma istekleri dışında "Türklüğün adını kötüye çıkarmama" ve "sözleşmenin iptal edilerek sınır dışı edilme korkusu" hususlarında hassas davranmış fakat bu kadar hassasiyetlerine rağmen işverenlerden çoğu zaman bekledikleri karşılığı alamamışlardır. Türk işçilerin bu süreçte en fazla sorun yaşadıkları hususlardan biri, yaşamlarını sürdürdükleri toplumun dilini bilmiyor oluşlarıdır. Karşılarına her alanda çıkan bu soruna bir çözüm bulabilmek adına Almanya da, Türkiye de hemen hemen hiçbir girişimde bulunmamıştır. Birtakım büyük iş yerleri ve sosyal yardım kurumlarının açmış olduğu dil kursları ise iş yoğunluğu ve birkaç yıl sonra geri dönme niyetleri gibi sebepler yüzünden amacına yeterince ulaşamamıştır (Başkurt, 2009: s. 83).

Almanya'daki Türk göçmenlerin değişik isim tanımlamaları da bulunmaktadır. Türkiye'de farklı giysi, tavır ve davranışları ile dikkat çekmiş ve gelir durumları da daha iyi olduğundan şımarıklık ve yukarıdan bakan tavırlara sahip olmakla itham edilerek "Almancı" olarak bilinmişler, Almanya' da ise toplumdan farklı oldukları için "Auslânder/Yabancı” olarak anılmışlardır. Kısaca onlar her iki ülkede de yabancı statüsündedirler. Bir başka ifadeyle her iki kültür arasında gidip gelmektedirler. Çünkü hem Almancı hem de Auslânder tanımlamalarında ötekileştirme bulunmaktadır. Ancak bu durum, onların zamanla bağlı oldukları her iki ülkeye de olumsuz bir tavır geliştirmelerine ve 
kısmen içe kapanmalarına neden olmuştur (Başkurt, 2009: s. 84). Göç alan ülkenin göçmenleri belirli haklardan yoksun bıraktığı, göç veren ülkenin ise bu insanların aidiyet duyacakları bir alternatif sunmadığı örneklerde göçmenlerin aidiyet duygusu devletleri ya da vatandaşlığı aşan akışkan bir nitelik kazanabilmektedir (Kılıç ve Menjivar, 2013: s. 204-205). Almanya'daki Türklerde de durum önemli ölçüde bu olmuştur.

\section{Kuşakların Oluşumu}

Türkiye ekonomisinde yaşanan olumsuzluklar, şiddet, baskı, terör ve siyasi çekişmeler, 1975 yılında yürürlüğe giren “çocuk parası düzenlemesi” gerekçesiyle Türkiye'deki çocuklara az para ödenmesi ve 12 Eylül 1980 askeri darbesi gibi nedenlerle, 1974 yılından itibaren Türkiye'den Almanya'ya doğru yoğun bir "aile birleşimi”" göçü başlamıştır. Bu tarihlerden itibaren artık işçi yurtlarından evlere taşınılmıştır (Başkurt, 2009: s. 83-84). Almanya bir göçmen ülkesi olmak istemediği için ülkedeki yabancıları misafir işçi olarak tanımlamıştır fakat zaman geçtikçe ve geri dönüşler gecikince bu insanlar "Mitarbeiter" (Çalışma/iş arkadaşı), ülkede kalıcı olmaya başladıklarında ise "Migranten" (Göçmenler) olarak anılmaya başlamışlardır (Başkurt, 2009: s. 84).

Kısacası, ilk başlarda Türk işçilere sadece misafir gözü ile bakıldığından ülkede geçici bir süreliğine bulundukları fikri hâkim olmuştur. Fakat zamanla içerisinde değişen işçi alım sözleşmesi ile birlikte çalışma izinleri de uzamış, yurtlardan çıkan Türkler, kendi imkânları ile konut kiralamışlardır. 1971 yılından itibaren ise aile birleşimiyle birlikte ev kiralamalar artmış ve yeni düzen oluşturmaya başlamışlardır. Bu ilk kuşak göçmenlerin yine geri dönüş yapacakları düşüncesinden kaynaklı olarak dinsel inanışları ile ilgili de çok talepte bulunmadıkları göze çarpmaktadır. Öyle ki Almanya' da Müslümanlar için ibadet yerleri yapımına bu insanların Almanya'ya gelişinden neredeyse 50 yıl sonra başlanacaktır (Gorlach, 2015).

Almanya yaşanan bu yoğunluk karşısında 1973 yılında işçi alımlarını bir süreliğine durdurma kararı almıştır. Bu şekilde yabancı işçilerin sayısında azalma amaçlanmış, misafir işçi olarak gelenlerin de bu düşünceden etkilenip ülkelerine geri dönmeleri beklenmiştir. Alman devletinin aldığı karar doğrultusunda Avrupa Ekonomik Topluluğu içinde yer almayan ülkelerden işçi alımı duracak, bulunan göçmen işçiler ise kısa bir süreliğine ülkelerine 
gidemeyeceklerdi. Ancak beklentilerin aksi gerçekleşmiş, göçmenler yerleşik bir düzene geçmeyi tercih etmiş ve geri dönmek yerine ailelerini de yanlarına almışlardır (Haksever, 2014: s. 76).

Almanya'da günümüzde üç kuşak Türk vatandaşı artık beraber yaşamaktadır. Bunlardan "Birinci kuşak” 1960'l1 yıllarda kısa süreliğine Almanya'ya gitmiştir. "İkinci kuşak Türkler” olarak tanımlanan grubu ise Almanya'ya ilk gelen vatandaşların çocukları oluşturmaktadır. Bu grup, yoğun olarak 1970'li yılların sonları ile 1980'li yılların ilk yarısında Almanya'ya göç etmiştir. Üçüncü kuşak Türkleri ise, birinci kuşağın torunları oluşturmaktadır. Bu kuşak, üzerinde sosyo-kültürel ve sosyo-ekonomik çalışmaların en çok yapıldığ 1 kuşaktır. Çünkü Almanya'da doğmuş olan bu kuşağın hayatlarını geçirecekleri topluma entegrasyon sürecinde milli ve dini kimliklerinin ne olacağı veya nasıl olması gerektiği, bir sorun olarak her iki ülke yetkililerince tartışılmaktadır (Başkurt, 2009: s. 85).

Kısacası, Türklerin Almanya'daki konum ve statüsü bu ülkede eskiden beri yoğun tartışmalara sebep olmaktadır. Almanya'da farklı kökenlerden gelen çok sayıda göçmenin yaşamasına rağmen Türkler sosyo-politik düzendeki önemleri ile bunlar arasında hakkında en fazla soru işareti bulunan grup olarak öne çıkmaktadır. Zira Türkler Almanya'daki en büyük göçmen grup olduğu gibi göçmen kitleleri arasında en az asimile olmuş olanıdır (Witte, 2018: s. 1426) Ülkedeki Türkler Almanya'nın toprak değil (jus soli), kan esasına (jus sanguinis) dayalı vatandaşlık sisteminden dolayı uzun süre Alman vatandaşl1ğı alma şansından da mahrum kalmışlar veancak 1990 yılından itibaren belirli koşullarda vatandaş olabilecekleri kabul edilmiştir (Stowasser, 2002: s. 53).

\section{Göç Literatüründe Almanya'daki Birinci Ve Üçüncü Kuşak Göçmenlerde Entegrasyona İlişsin Veriler}

\section{Birinci Kuşak}

Almanya Büyükelçiliğinin iki ülke arasında yapılan anlaşmanın 50. yılına istinaden hazırladığ ç çalışmada çeşitli bilgilere yer verilmektedir. Bu kapsamda Türk işçilerin Almanya'ya kabul edilme süreçlerinde hangi yollardan geçtikleri belirtmektedir. "Almanya, İstanbul'un Tophane semtinde bir irtibat bürosu kurmuştu. Almanya'ya gitmek isteyen insanlar bu büroya müracaatta bulu- 
nuyor, ardından memleketlerine geri dönüp, bürodan gelecek "Almanya kağdını" bekliyorlardı. Mektubu alan irtibat bürosuna koşuyor ve Almanya'ya gidiş çilesi başlyyordu Aralarında belki de o güne kadar hiç doktora gitmemiş kişilerin de bulunduğu işçiler, Alman doktorlar tarafindan sikı bir sağlık kontrolünden geçiriliyordu. İşçiler, dişlerine kadar kontrol ediliyorlardı. Sağlam olanlar, köylerine kentlerine gidip, Almanya'ya gitmek üzere tahta bavulların hazırlyyor ve 1-2 yıllı̆̆ına, 3-5 kuruş biriktirdikten sonra geri dönme düşüncesiyle uzun bir yolculuğa başllyorlardı.” (Haksever, 2014: s. 71)

Almanya'ya, imzalanan anlaşmadan sonraki ilk on yıllık dönemde giden Türkler Birinci Kuşak olarak kabul edilmektedir. Bu kuşağın mensupları Almanya'ya giderken bu ülke hakkında neredeyse hiçbir bilgiye sahip değildirler. Birinci kuşak Türk işçileri, Alman toplumu tarafından da merak ve şaşkınlıkla karşılanmıştır, zira Türk işçileri kültürel açıdan onlardan oldukça farklı bir yapıdadır. Bu farklılıklar inançta, dinde, dilde, örf-adetlerde, geleneklerde ve eğitim gibi alanlarda görülmektedir. Birinci kuşağın, içine girdikleri bu farklı kültür ile olan iletişimleri ve etkileşimleri sınırlı düzeyde kalmıştır, çünkü bu kuşak göçmenler ev sahibi ülkenin dilini hiç bilmemektedir ve ancak "kulaktan dolma" (spontaneous learning) birkaç cümle öğrenebildiklerinden içinde yaşadıkları topluma mesafeli bir hayat yaşamışlardır (Aksoy, 2010: s. 14). Yani birinci kuşak Türklerin belirgin özellikleri Almanca bilmemeleri ve Almanya'da işçi olarak istihdam edilmiş olmalarına rağmen, buraya kısa bir süre için gelmiş ve mesleki anlamda kalifiye olmayan insanlar olmalarıdır (Şahin, 2012: s. 3) Bu kuşaktaki Türkler ağırlıklı olarak kas gücü gerektiren zor işlerde çalıştırılmış, mesleki deneyimlerini de bu koşullarda çalışarak kazanmışlardır. Birinci kuşak göçünün gerçekleşmesinin üzerinden birkaç yıllık bir süre geçtikten sonra, kültürel ve sosyal karşıtlıklar ortaya çıkmaya başlamıştır. Almanya'ya giden ilk kuşak olan Türklerin çocukları, Alman eğitim sistemine uyum sağlayamamışlardır. Eğitimde yaşadıkları sorunların en önemli nedenlerinden biri yine dil sorunu olmuştur.

Özellikle 1980'lerden itibaren ise Almanya'da yabancı kültüre yönelik karşıtlık gözlenmeye başlamış ve Türklere dönük birtakım saldırılar gerçekleştirilmiştir. Aksoy'a (2010: s. 15) göre Almanya'da bulunan ikinci ve üçüncü kuşak Türkler, bu ülkede ırkçı nitelik taşıyan yabancı düşmanlığından en çok etkilenen ve de en fazla hedef olarak gösterilen azınlık grubu olarak dikkat çekmektedir. 
İlk kuşaktan itibaren yaşanan yabancı düşmanlığı sorunu diğer kuşaklarda da artarak devam etmiştir. Yalçın (2006: s. 57) artan yabancı düşmanlığının sebebi olarak şu hususu belirtmektedir: İlk kuşak Türkler sadece Almanya' daki ekonomik yapının gereksinim duyduğu işlerde çalışmışlar ve bu yüzden de bulundukları ülkenin çoğunluk toplumu ile rekabet edememişlerdir. Ev sahibi toplumun çalışmak istemeyecekleri işlerde çalışan birinci kuşak Türkler, Alman işçiler için en başta bir tehdit unsuru olarak da görülmemiştir. Dil bilmiyor oluşları ve eğitim düzeylerindeki düşüklük de göz önünde bulundurulursa ilk kuşak Türkler için ırkçılık problemlerinin bugünkü kadar olduğunu söylenemez. Irkçılık ya da yabancı düşmanlığını doğuran en temel etken, ikinci ve üçüncü kuşak göçmenlerin bulundukları toplumda edindikleri eğitim ve kültürle o toplumdaki yerli vatandaşla iş ve yüksek öğretim alanlarında rekabete girebilmeleri, büyüklerinin yapmış oldukları işleri yapmak istememeleridir.

\section{İkinci Kuşak}

Birinci kuşak Türkler Almanlar tarafından misafir işçi olarak tanımlanmış, bu nedenle de Almanya misafir olarak nitelendirdiği bu Türkler için bir entegrasyon politikasını gerekli görmemiştir. 1974'ten 1984 yılına kadar olan süreçte ise Almanya'da ikinci kuşak Türkler yetişmiştir. Alman hükümetinin 1984 yılında çıkarmış olduğu “Geri Dönüş Teşvik Yasası” beklendiği gibi etkili olmamış, Türklere belli bir ücret karşılığında geri dönemleri teklif edilmişse de Türkler geri dönmek istememiştir. Alman devleti geri dönüşlerin yüksek oranda olacağını düşünmüştür ama teşvik yasasından yararlananların sayısı bir hayli düşük olmuştur. Geri dönenler ise birinci kuşaktaki kişilerdir. Yasadan yararlananlar çocuklarının bir şekilde Almanya'da kalmasını sağlamışlardır ve bu şekilde Almanya ile olan bağları da kopmamıştır. Almanya'daki Türk varlığının devamlılığını sağlayanlar işte bu gruptakilerdir.

İkinci kuşak Türklerin belirgin özellikleri şunlardır: Almanya'ya ilk olarak gelen birinci kuşağın çocuklarıdır veya aile birleşiminden yararlanarak gelmişlerdir. Almancayı kısmen bilmektedirler ve önemli bir kısmı Alman okullarında eğitim görmüştür. Almanya'da ikinci kuşağın oluşmasıyla birlikte Alman hükümeti, oluşturdukları yasaya rağmen Türklerin ülkelerine geri dönmeyeceklerini, ülkedeki varlıklarının devam edeceğini anlamıştır. Durumun bu hale gelmesinden sonra Alman yetkililer, Türklerin Almanya'ya uyum sağlaması için birtakım politikalar uygulama kararı alacaktır. 
İkinci kuşak Türkler, sadece Almanya'daki Türk varlığının devamını sağlamakla kalmamış, sosyal ve kültürel yaşamda da varlıklarını topluma kabul ettirmişlerdir. Yani, birinci kuşağın yapmış oldukları birikimleri, sosyal yapıda kazanca dönüştürmüşlerdir. Bu kuşakta yer alan Türkler, Alman toplumuyla olan etkileşimlerini hızlandırmışlardır. Her alanda varlıklarını devam ettirmiş ve o toplumda kendilerini göstermeye çalışmışlardır (Şahin, 2012: s. 5). Bununla birlikte, Türkler için Almanya'da gerçekleşen değişim ortamının kazanımları gibi götürüleri de olmuştur. Değişen aile yapısı nedeniyle "parçalanmış aileler" olarak tanımlanan olumsuz bir durum ortaya çıkmıştır. Ama ekonomik anlamda olumlu gelişmeler yaşanmış, Türk göçmenlerin refah seviyeleri artmıştır. Bununla birlikte yine de 1970 'lerin sonundan itibaren Türklerin işsizlik oranının toplam işgücünün üzerinde olduğu söylenmelidir. Öyle ki Türklerde 1990'da \%10 olan işsizlik oranı 1997'de \%24'e kadar yükselmiştir (Tol, 2012: s. 307).

İkinci kuşak Türklerin, genel olarak en şanslı grup olduğu belirtilmektedir. En önemli avantajları, içinde bulundukları yabancı ülkeye uyum sağlama gibi bir problemle karşılaşmamış olmalarıdır. Ancak bu noktada, ikinci kuşağın Almanya'da doğan temsilcileriyle, Türkiye'den çocuk ya da genç yaşta aileleri tarafından Almanya'ya getirilen üyeleri arasında bir ayrım yapılması gereklidir. Almanya'da doğup büyüyen ve Alman okullarında eğitim görenler haliyle Almancayı çok daha iyi bilmektedirler ve aynı zamanda evde de aile içerisinde Türkçe konuşulduğu için Türkçeye de hâkimdirler. Diğer gruptaki Türkler ise çevreye zamanla uyum sağlayabilmiş ve Almanlarla ilişkilerini daha geç geliştirebilmişlerdir (Kırmızı, 2016: s. 152). Yılmaz'ın da (2013: s. 1313) ifade ettiği gibi insanlar "konumuna göre yeni arkadaşlar edinir, bünyesinde şekillendiği toplumdan zaman içerisinde farklı düşünebilir ve gördüğ̈̈ eğitimle doğru orantılı olarak kendisine sunulan fikirlerden doğru ve kendi dünyasına yakın bulduklarını benimseyerek farklı düşünceler edinmeye başlar”. Bu anlamda Türkiye'de doğup daha sonra Almanya'ya götürülen çocuk ve gençler yurt dışında bazı güçlüklerle daha yoğun mücadele etmek durumunda kalmışlardır.

\section{Üçüncü Kuşak}

Üçüncü kuşak Türkler, 18-29 yaş arasındaki göçmenlerden oluşmaktadır. $\mathrm{Bu}$ gruptaki bireyler diğer kuşaktakilere göre Alman toplumuyla çok daha 
yakın ilişki içinde olmuşlardır. Almancayı Türkçeden çok daha iyi bilmektedirler ve arkadaş grupları genellikle Almanlardan oluşmaktadır. Almanya'nın yürüttüğü entegrasyon çalışmalarının sonuçları en belirgin şekilde bu kuşakta görülmektedir. Zira üçüncü nesilde, Türk kimliğinden görece kopuk, ailesiyle belirli anlaşmazlıkları olan ve önceki kuşaklarla birtakım çatışmalar içerisinde bulunan gençler yetişmeye başlamıştır.

Üçüncü kuşaktakilerin neredeyse tamamı Almanya'da doğup büyümüş ve Alman toplumun kültürel değerleri ile daha fazla iç içe olmuş kişilerdir. "1. Kuşağa göre 3. ve 4. Kuşak çok daha eğitimli ve Almanya'daki sosyal ve iş yaşamının içinde yer almaktadır" (Kırmızı, 2016: s. 153). Eğitim hayatına direkt olarak Alman okullarında başladıkları için eğitim yönünden bir güçlükle karşılaşmamışlardır. Üçüncü kuşağın aile büyüklerine göre sosyalleşme sürecini çok daha rahat geçirdiği söylenebilir. Bu bireylerin en büyük problemleri ise Türk kültürüne ve diline karşı yabancılaşmalarıdır. Bu duruma hassasiyetle yaklaşan aileler onlara Türkçe öğretmeye çalışsa da bu konuda yeteri kadar başarılı olamamışlardır.

Birinci kuşakta yer alan ve aynı zamanda üçüncü kuşak Türklerin dedeleri olan Türkler neredeyse hiç Almanca bilmezken, ikinci kuşak her ikisine de hâkimdir, üçüncü kuşak ise \%90 oranla sadece Almanca bilmektedir ve bu kuşak içerisinde yer alan kişiler kendi ailelerinin anadillerine yabancı kalmışlardır (Kırmızı, 2016: s. 154-155). Okulda derslerin Almanca verilmesi, arkadaşlarının büyük bir kısmının Alman oluşu ve her şeyden önemlisi de sosyal yaşantılarının onları Almanca konuşmaya zorlaması buna neden olan faktörler olarak gösterilebilir. Türkçe konuşma kabiliyetlerinin kısıtlı oluşu Türk kültürüne ve Türkiye'ye karşı bazı önyargılar beslemelerine de neden olabilmektedir. Almanya'da bütünleşmeyi olumsuz k1lan birçok unsura rağmen üçüncü kuşakta yer alan Türkler çoğunlukla Alman vatandaşlığını tercih etmektedirler (Kırmız1, 2016: s. 153-154).

Almanya'daki üçünü kuşak Türklerin genel özelliklerinin, Almanların Türkler için uyguladığı entegrasyon çalışmalarının bir sonucu olduğu söylenebilir. Avrupa'daki etnik azınlıkların bugünkü durumlarına bakılacak olursa, Avrupa'daki sistemin temel kaygısının ikinci ve üçüncü kuşak Türkleri topluma absorbe etmenin yollarını bulmak olduğu görülmektedir. Fakat burada dikkat çekici olan, üçüncü kuşaktaki değişimin çoğu örnekte entegrasyonu dahi aşacak bir düzeyde gerçekleşmiş olmasıdır. Kavramsal kısımda da dikkat 
çekildiği gibi, entegrasyonda temel amaç kültürel çoğulculuğun sağlanması ve toplumlararası iletişim ve etkileşimin bu yolla teminidir. Bu durumda azınlık grupların çoğunluğun kültürel ilkelerini edinirken topluma kendi kültürel özelliklerini de bir dereceye kadar katması beklenir olandır. Ancak Almanya'daki üçüncü kuşak Türklerde ailelerinin anadili, kültürel kökeni ve kimliğine yönelik bağl1lık son derece zayıflamış ve onun yerini güçlü biçimde Alman kültürü ve yaşayış tarzı almış gibi gözükmektedir. Öte yandan, bu genç neslin mevcudiyeti ve Alman kültürüne angajmanı Almanya'nın gelecek vizyonu için son derece önemlidir, zira araştırmalar, Almanya' daki mevcut doğum oranına göre ülkenin halihazırda 82 milyon olan nüfusunun 2050 yılı itibariyle 60 milyona kadar düşebileceğini göstermektedir (Mueller, 2006: s. 426).

\section{Birinci ve Üçüncü Kuşak'ın Entegrasyon Değerlendirmesi}

Kuşaklararası uyuşmazlık her yerde ve dönemde görülen bir olgudur. Çatışma, genel anlamda uyuşmazlık, karşıtlık ve anlaşmazlık gibi durumları içermektedir. Çatışmalar; düşünce, duygu, çıkar, beklenti ve amaç gibi durumlarda oluşan farklılıklardan doğmaktadır. İnsanlar arasında bu yönlerden her zaman uyum ve denge görülmesi oldukça güçtür. Bu nedenle insan topluluklarının olduğu her yerde çatışma görülür. Bu çatışma, yeni fikir ve değerlere açık olan gençlerle, daha tutucu ve geleneksel değerlere bağlı yetişkinler arasında neredeyse kaçınılmazdır. Kuşaklararası çatışma; konuşma biçimi, giyim-kuşam fark1, beğeniler, dünya görüşü, ideolojik inançlar gibi alanlarda görülebilmektedir (Yeşilyaprak, 1989: s. 50). Çatışmanın en önemli nedeni ise kuşakların birbirlerine ön yargı ile yaklaşması ve birbirilerinin görüşlerine saygı duymamasıdır.

Teknolojik gelişmelerin sosyal yaşamda yarattığ değişmeler, boş zaman kavramı, artan toplumsal hareketlilik, makineleşme; bilgi patlaması, kültürlerarası alışverişin hızlanması gibi gelişmelere bağlı olarak kuşakların farklı biçimde toplumsallaşma süreci geçirmesi çatışmaya neden olmaktadır. Çünkü toplumsal değişmelerle birlikte inançlar ve değerler de değişmektedir. Yaşlı kuşak geleneksel değerlere sarılırken, genç kuşağın yeni değerlere açık olmaS1 çatışmayı hazırlamaktadır (Yeşilyaprak, 1989: s. 51).

Yapılan araştırmalar çerçevesinde en başta Almanya olmak üzere Avrupa ülkelerinde yaşayan Türk gençlerin adaptasyon sorunları geçmişten bu zamana kadar tespit edilmeye çalışılmıştır (Bedirhan, 2009: s. 4). Özellikle son zaman- 
larda Fransa'da yaşanan kundaklama olayları Almanya'nın gündeminde önemli yer tutmaya başlayınca töre cinayetleri ve şiddet olayları ile göçmen çocukların uyum sorunuyla ilgili çalışmalar hız kazanmıştır (Gökçe, 2006: s. 11).

Toplumsallaşma aşamasında, gençler içindeki bulundukları toplumun değerlerini ve normlarını öğrenirken, ailelerinin değer ve kurallar sistemi farklı olduğu için sorun yaşamaktadırlar. Kendi kültüründen çok başka olan toplumsal yaşam koşulları, göçmen Türk gençlerini toplum dışına doğru sürüklemektedir. İşsiz gençlerin suç ortamlarına itilmesi, marjinal grupların etkisi altına girmesi, entegrasyon deneyimlerinin olumsuzluğunun bir göstergesidir. Bu gençler alkol, kumar ve uyuşturucu gibi kötü alışkanlıklara ve suç işlemeye meyilli hale gelmektedir. "Marjinal konuma itilen gençler eğitim ve iş bulma konusunda karşılaştıklarl ayrımcllı ve dışlanmay kabullenememektedir. Toplumun baskın kültürünün yanında kendi kültüründen de ayrllarak alt-kültürler oluşturmakta, bu da kültür çatışmalarında belirleyici etken rol oynamaktadır. Marjinal gençlerin bir yandan çok yönlü sorunların sahibi olmast, diğer yandan bir alt-kültür olarak görülmeleri onların kural dışı davranışlarının nedenidir”' (Bedirhan, 2009; Canatan, 1990).

Birinci ve üçüncü kuşak Türklerin entegrasyon değerlendirmesinde ilk olarak dil konusu dikkat çekmektedir. 1961'de yapılan anlaşmayla gelen Türklerin amacı para kazanıp birikim yapmak ve ülkelerine dönmekti. Almanca bilmeyen bu kuşaktan sonra entegrasyon çalışmalarıyla birlikte diğer kuşaklar çok iyi Almanca konuşur duruma gelmiştir. Dedeleri hiç konuşamazken üçüncü kuşak Almanya'da doğup büyüdüğü için dil konusunda sorun yaşamamıştır. Fakat bu kuşağın en önemli sorunu Türkçeyi konuşamıyor olmasıdır. Alman okullarında verilen Türkçe dersler de entegrasyon çalışmaları neticesinde kaldırılınca Türkçe bilmeyen bir nesil yetişmiştir. Veya çok az Türkçe bilen; evde Türkçe konuşup dışarda Almanca konuşan bireyler her iki dil arasında sıkışıp kalmıştır.

Adıgüzel'e (Adıgüzel, 2011: s. 233) göre, Alman dilinin göçmen Türklere öğretilmesi "entegrasyon çalışmasının” ilk ve en temel aşaması olarak görülmektedir. Almanlar, kendi milletlerini Almancaya verdikleri değerle yarattıklarından, yabancıların Alman toplumuna uyumu önündeki en önemli engeli de kendi ülkelerinin dilini konuşmaları olarak görmektedirler. Bu durumda, mesele Türklerin adaptasyon/entegrasyon sorunu olmaktan ziyade, göçmenlerin "dil ve kültürel farkl1lıklar” yüzünden doğrudan "problem” olarak görülmeleridir. 
İki kuşak arasında görülen farklılıklardan bir diğeri de "eğitim” alanındadır. İşçi alımı sözleşmesiyle gelen birinci kuşak Türklerin eğitim seviyesi ilkokul düzeyindedir ve Almanya'ya ancak o şekilde kabul edilmişlerdir. Misafir işçilikten çıkıp oraya yerleşen Türklerin bir kısmının çocukları ve daha sonraki kuşaklar Alman okullarında eğitim görmüştür. Bu yüzden Alman toplumunun kültürel değerlerini ve yaşam tarzını edinmiş, Türk kimliğinden ve değerlerinden ise önemli derecede uzaklaşmışlardır. Zaten entegrasyon çalışmalarının en hassas noktası da budur. Alman hükümeti ileride yaşayacağı genç nüfus sıkıntısını düşündüğü için Türk göçmenlerin özellikle genç kesimini kendi kültürel kimlik ve değerleriyle yoğurmaya çalışmakta ve bu insanlara Alman kültürel özelliklerini kazandırmaya yönelmektedir.

Dil ve eğitim alanında görülen farklılıklar kuşaklararası anlaşmazlıklara neden oluşturmakta, birinci ve üçüncü kuşak arasında kültürel çatışmalar yaşanmaktadır. Birinci kuşak Türk göçmenler, genç yaşta yabancı bir ülkeye geldikleri için kendi milli değerlerine yani Türk kimliğine sıkı sıkıya bağlanmış, kendilerini bu şekilde koruma altına almışlardır. Daha sonra gelen kuşaklarda ise bu özellik azalmış ve üçüncü kuşakta en alt seviyeye düşmüştür. Kimlik ve kültür olarak farklı konumda oldukları için diğer iki kuşakla aralarında birtakım sorunlar vardır. Üçüncü kuşak Alman toplumunda doğup yaşamlarını devam ettirdiği için Türk kimliği ve değerlerinden oldukça uzak bir nesildir. Birinci kuşağın dayatmalarını ve baskılarını kabul etmemektedirler. Türkiye'deki gençler aileye ve topluma daha bağlı iken, Almanya'da gençler olaylara daha bireyselci bir bakış açısıyla yaklaşmaktadırlar. Bu durumu kabul etmeyen ailelerin çocukları ise evden uzaklaşarak çok daha farklı ve hatta negatif ortamlara girebilmektedirler.

Bunun dışında, üçüncü kuşağın belirli temsilcileri her iki kültürden de k1sım ilkeler edinmiştir. Ne tam olarak Alman ne de tam olarak Türk’türler, daha çok her iki kimlik arasında sıkışıp kalmış durumdadırlar. Bu gruptakiler "Riskli" olarak tanımlanmaktadır. Haksever' in (2014: s. 19) de ifade ettiği gibi kuşaklar attıkça her iki kültürden de yarım bilgileri olan ne tam olarak Türk kimliği ne de Alman kimliğine girebilen nesiller oluşmaktadır. Türkçe konuşmakta sıkıntı çeken ve zorlandığı yerde Almanca konuşan, tam tersi bir durumda ise tekrar aynı yolu izleyen bir kuşaktan bahsedilmektedir. Bu kuşaktaki Türkler Almanya'da bambaşka bir kültürel yapının içinde bulunmakta ama aileleri tarafından da kendi kültürel değerleri içinde tutulmaya 
çalışılmakta, bu durumda da aynı anda çok farklı iki kültürü de tam anlamıyla benimsemekte güçlük yaşamaktadırlar.

Kuşaklar arasındaki diğer bir karşılaştırma ise "tanınan haklar" konusundadır. Çok uzun yıllardan bu yana Almanya'da bulunmalarına rağmen ve oraya yerleştikleri kesinleşmiş olmasına rağmen Türklerin çoğuna halen daha seçme ve seçilme gibi en temel haklar tanınmamaktadır. Bu durum, Türklerin kendi sosyal yaşantılarında geleneksel değer, örf ve adetlerine aşırı bağlllık ve bu bağlılığın bir sonucu olarak kısmen marjinal siyasi ve dini yapılanmaların içerisine düşmelerine neden olan "ötekileştirme" uygulamalarından biridir (Başkurt, 2009: s. 89). Haklar konusundaki diğer bir husus da şudur: Birinci kuşaktaki Türk göçmenler geçici olarak para kazanma isteği ile gelmişlerdir ve geldiklerinde Alman toplumundan hak ve hukuk bağlamında beklentileri olmamıştır. Göçün ilk yıllarında yaşadıkları zorluklara ve işverenlerin baskılarına tepki vermemişlerdir. Fakat daha sonraki kuşak kalıcı olmalarından itibaren bazı haklar ve kazanımlar elde etmişlerdir. Ekonomik durumlarındaki gelişmeleri ve anavatanlarına geri dönmeyi istememeleri de bu durumun bir göstergesidir.

Birinci kuşak göçmenler, arkadaş çevrelerini genel olarak Türklerden kurmakta ve evlilik konusunda büyük bir yoğunlukla yine Türkleri tercih etmekte iken, üçüncü kuşak göçmenlerin arkadaş çevrelerinin çoğu Almandır ve Almanlarla evlilik yapmaya da sıcak bakmakta, hatta eş seçimlerini Türkler yerine Almanlardan yapmayı daha fazla istemektedirler. Muhafazakâr ailelerde yetişen gençlerin dahi böyle bir yönelimde bulunması dikkat çekicidir (Yurdakul, 2018: s. 157).

Özellikle üçüncü kuşakla ilgili olarak, çifte vatandaşlık konusu üzerine ortaya atılan karşıt fikirler ise son dönemde daha fazla güç kazanmış durumdadır. İki ülkeye birden sadakat duymanın ne derece olası olduğu sorgulanmakta ve Türkler iki alternatiften birini seçmeye zorlanmaktadır. Almanya'da Alman vatandaşlığını 2000 yılı öncesinde almış olanların çifte vatandaş olabilmelerine izin verilirken diğerleri, yani üçüncü kuşağın üyeleri için bu hak tanınmamakta, 23 yaşına kadar tercihlerini yapmaları beklenmektedir (Dempsey, 2013). Böylece Almanya'daki genç Türklerin tek sadakat odaklarının Almanya olması sağlanmaya çalışılmaktadır.

Almanya'da yaşayan Türk göçmenlerin kuşaklararası entegrasyonu kimlik, kültürleşme, sosyo-ekonomik etkinlik gibi konularla doğrudan ilgilidir. Ku- 
şaklar ilerledikçe Alman kültürünü benimseme düzeyinin arttığı görülmektedir. Fakat bu durumda Türk kültürünü ve benliğini devam ettirme düzeyi düşmektedir ve bu şekilde entegrasyondan daha ileriye gidilmekteve asimilasyona yaklaşılmaktadır. Bu durum doğal bir sürecin sonucu olmaktan çok Alman hükümetinin uyguladığ yasal ve politik düzenlemelerden kaynaklanmaktadır. Çünkü Almanya'nın genç nüfusa ihtiyacı vardır ve üçüncü kuşak Türk göçmenleri geleceğe yönelik bir potansiyel olarak görmektedir. Dolay1sıyla Almanya' da yaşayan Türk göçmenlerin zihniyet dönüşümümde Alman devletinin uyguladığı politikaların önemli bir payı söz konusudur.

\section{Sonuç}

Göç olgusu ve bununla birlikte entegrasyon ve asimilasyon meseleleri sosyal bilimler alanında incelemeye alınan ve sıklıkla karşımıza çıkan konulardandır. Bu çalışmada 1961 yılında imzalanan "İş̧̧i Alımı Sözleşmesi”" ile Almanya’ya giden ilk kuşak Türk göçmenler ile üçüncü kuşak göçmenler entegrasyon ve asimilasyon kavramları çerçevesinde karşılaştırılmalı olarak incelenmiştir. Kuşaklararası farklar dikkate alınarak bu bağlamda Türk kimliğini devam ettirme ve benimseme, Türklerle iletişim kurma, Alman kültürünü benimseme ve Alman diline hâkim olma gibi unsurlar incelenmiştir.

Çalışmanın üzerinde durduğu başlıca noktalar ve vurguları şu şekilde özetlenebilir: Almanya'ya ilk giden kuşak para kazanmak amacıyla geçici süreliğine oraya gitmiştir. Fakat misafir işçi statüsüyle orada çalışan Türk göçmenler daha sonra geri dönmek istememiş, aile birleşimi yasasından yararlanarak ailelerini de yanına almış ve artık Almanya'da kalıcı olmuşlardır. Alman devleti Türk göçmenlerin kısa bir süreliğine gelip daha sonra geri dönecekleri düşüncesinde olduğu için başlarda yasal bir önlem almaya gereksinim duymamıştır. Türk göçmenlerin geri dönmeyecekleri anlaşıldığında ise belirli sosyal ve politik uygulamalar getirmiştir. Entegrasyon arayışı bu politikaların en başında gelmektedir. İkinci kuşak Türk göçmenler ise birinci kuşağın çocuklarıdır. Bir kısmı Türkiye'de doğmuş ve daha sonra oraya götürülmüş, bir kısmı ise Almanya' da dünyaya gelmiştir. Entegrasyon çalışmaları bu kuşakta başlamıştır. Birinci kuşak göçmenler hiç Almanca bilmemekte, Türk kimliğine ve kültürel değerlerine sıkı sıkıya bağlı kalmaktadır. Alman toplumuyla iletişimleri çok düşük seviyededir. Ama onların çocukları anne-babalarına göre daha 
iyi Almanca konuşmakta ve Alman okullarında eğitim almaktadırlar. Alman toplumuyla iletişim kurmuş ve sosyalleşmişlerdir. Alman hükümeti entegrasyon çalışmaları yaparak bu çocuklara okullarda \%90 Almanca eğitim vermiş, onlara Alman kültür ve değerleri öğretilmiştir (Şen, 2010: s. 121-131). Verilen kısıtlı Türkçe eğitim de bir süre sonra kaldırılmıştır. Bu sebeple ikinci kuşak Türkçeyi aile ortamında öğrenmiştir ve her iki dile ve kültüre de aşinadır. (Adıgüzel, 2011: s. 239).

Alman devletinin en çok önem verdiği ve hedefindeki grup ise üçüncü kuşaktır. Çünkü Almanya ileride yaşayacağı genç nüfus sıkıntısını düşünerek bu kuşağ kendisine bir potansiyel olarak görmektedir. Bu yüzden de bu kuşağ tıpk1 bir Alman gibi yetiştirmek istemiştir. Entegrasyon çalışmaları bu kuşakta daha ileriye giderek asimilasyona dönüşmüştür (Şahin, 2012: s. 230). Çünkü üçüncü kuşak göçmenler önceki kuşaklardan çok farklıdır. En başta Almanya'da doğmuş ve büyümüş, Alman okullarında eğitim almışlardır ve Türkçeden çok daha iyi bir şekilde Almanca konuşabilmektedirler. Bu kuşaktakiler ilk kuşak göçmenlere kıyasla Türk kültür ve değerlerine oldukça uzaktırlar. Türkçeyi çok az bilmektedirler ve Türk kültürel değerlerine de yakın değildirler. Bu yüzden birinci kuşakla, Alman toplumuna ayak uydurmuş, Alman kültür ve değerlerini benimsemiş üçüncü kuşak arasında sık sık çatışma yaşanmaktadır.

Çalışmanın temel iddiasından yola çıkılarak varılan sonuç, Almanya'daki Türk göçmenlerin kuşaklar ilerledikçe Türk kimliğini ve kültürünü benimseme düzeylerinin düşeceği yönünde olmuştur. Çalışma sırasında görülmüştür ki entegrasyon politikası, genç kuşakların Alman dili ve kültürüne aidiyetinin sağlanması hususunda Alman devletinin yürütmekte olduğu bir çalışmadır ve bu çoğu zaman asimilasyona dönüşmektedir. Bu Şahin'in (2010: s. 124), üçüncü kuşak ve sonrasındaki kuşakların gittikçe Alman kültürünü benimseyeceği ve böylece uygulanan entegrasyon politikalarının dördüncü kuşak ve sonrası için hiçbir baskı olmaksızın asimilasyona dönüşeceğini iddia eden Esser'e (2000: s. 55) yönelttiği eleştirinin doğruluğunu göstermektedir. Bir başka ifadeyle yeni kuşaklar kendiliğinden asimile olmamakta, devletin uyguladığı entegrasyon politikaları örneğin Türkçenin ders olarak kredili şekilde okunmasının kaldırılması, çifte vatandaşlık hakkının sınırlandırılması, tek kültürü benimseyenlerin daha çabuk iş bulabilmesi gibi durumların bir sonucu olarak ortaya çıkmaktadır. 


\section{Kaynakça/References}

Adıgüzel, Y. (2011). “Almanya'da Kültürel Çatışma Alanı Olarak 'Türkçe””. Sosyoloji Dergisi, 22(3), 231-251.

Aksoy, E. (2010). “Almanya’da Yaşayan Üçüncü Kuşak Türk Öğrencilerin Kimlik Alg1lamaları ve Buna Bağlı Olarak Karşılaştıkları Ayrımcılık Sorunları”, Hacettepe Üniversitesi Türkiyat Araştırmaları Dergisi, 12, 7-38.

Algan, Y., Bisin, A. ve Verdier, T. (2012). "Introduction: Perspectives on Cultural Integration of Immigrants", Algan, Y., Bisin, A., Manning, A. ve Verdier, T. (ed.), Cultural Integration of Immigrants in Europe, Oxford: Oxford University Press, 1-48

Başkurt, İ. (2009). “Almanya'da Yaşayan Türk Göçmenlerin Kimlik Problemi”, Hasan Ali Yücel Eğitim Fakültesi Dergisi, 12, 81-94.

Bedirhan, Y. (2009). “Avrupa Birliği Ükelerinde Yaşayan Türk Çocuklarının Kültürel Uyum Sorunları ve Çözüm Önerileri”, Akademik Bakış, 16, 1-7.

Benhabib, S. (2006). Ötekilerin Hakları, Yabancılar, Yerliler, Vatandaşlar. Çev. Berna Akkıyal, İstanbul: İletişim Yayınları.

Bilgin, N. (2007). Kimlik İnşası. İzmir: Aşina Kitaplar.

Canatan, K. (1990). Göçmenlerin Kimlik Arayışı. İstanbul: Endülüs Yayınları.

Chin, R. (2007). The Quest Worker Question in Postwar Germany. New York: Cambridge University Press.

Dempsey, J. (2013), “A Difficult Choice For Turks in Germany”, 30 Temmuz 2018 tarihinde çevrimiçi https://www.nytimes.com/2013/04/16/world/europe/16iht-letter16.html

Esser, H. (2000). "Integration and Ethnic Stratification," Hartmut Esser et al. (ed.), Towards Emerging Ethnic Classes in Europe? Volume 1 Workshop Proceedings, Project Conclusions, Integration and Ethnic Economy and Social Exclusion, Weinheim; Freudenberg-Stiftung, 49-84.

Gitmez, A. (1983). Yurt Dışına İşçi Göçü ve Geri Dönüşler: Beklentiler Gerçekleşenler. İstanbul: Alan Yayınları.

Gorlach, A. (2015). “To Integrate the New Refugees, Germany Must Avoid Its Mistakes with Turkish Immigrants”, 30 Temmuz 2018 tarihinde çevrimiçi https://www.huffingtonpost.com/alex-gorlach/refugees-germany-turkey-immigrants_b_8148264.html

Göç Terimleri Sözlüğü (2009). Cenevre: IOM (Uluslararası Göç Örgütü).

Gökçe, O. (2006). “Almanya'da Uyum ve Dışlanma Arasında Türk Gençleri”, Türk Yur$d u, 224,9-17$.

Gülboy, P. E. (2015). Sömürgeden Ulus Devlete Çok Etnikli Coğrafyada Yaşam. İstanbul: Kalkedon Yayınları.

Haksever, A. (2014). Federal Almanya'da Göç ve Entegrasyon Politikaları. Ankara: Yurtdışı İşçi Hizmetleri Uzmanlık Tezi. 
Kakışım, C. (2018). “Turkey’s Current Position in the Way of Multiculturalism: Legacy of Past and Today's Dead-End”, European Journal of Multidisciplinary Studies, 7(1), 62-72. Kartari, A. (2006). Farklılıklarla Yaşamak: Kültürlerarası İletişim. Ankara: Ürün Yayınları. Kırmızı, B. (2016). “Göçmen Türklerin Almanya’da Yaşadığı Sorunların Dünü ve Bugünü’, Journal of Turkish Language and Literature, 2(3), 145-156.

Kılıç, Z. ve Menjivar, C. (2013). "Fluid Adaptation of Contested Citizenship: Second-Generation Migrant Turks in Germany and the United States”, Social Identities, 19(2), 204-220.

King, R. ve Kılınç, N. (2014), “Second-Generation Turks from Germany 'Return' to Turkey”, Nordic Journal of Migration Research, 4(3), 126-133.

Kümbetoğlu, B. (2003). Uluslararası Göç, Toplumsal Cinsiyet ve Güvenlik, Uluslararası İlişkilerde Sınır Tanımayan Sorunlar. İstanbul: Bağlam Yayınları.

Mueller, C. (2006), "Integrating Turkish Communities: A German Dilemma", Population Research and Policy Review, 5(6), 419-441.

Mutluer, M. (2003). Uluslararası Göçler ve Türkiye. Denizli: Çantay Yayınları.

Öztürk, M. (2011). Avrupa Birliği Göç Politikaları: Almanya'daki Türk Iş̧̧ileri . İstanbul: İstanbul Üni. AB Anabilim Dalı Yüksek Lisans Tezi.

Park, Robert E. ve Burgess, E. (1969). Introduction to Science of Sociology. Chicago: University of Chicago Press.

Perşembe, E. (2005). Almanya'da Türk Kimliği. Ankara: Araştırma Yayınları.

Sosyal Bilimler Ansiklopedisi. (1988). İstanbul: Risale Yayınları.

Stowasser, B. F. (2002), “The Turks in Germany: From Sojourners to Citizens”, Yvonne Yazbeck (ed.), Muslims in the West: From Sojourners to Citizens, New York: Oxford University Press, 52-71.

Şahin, B. (2010). “Almanya’daki Türk Göçmenlerin Sosyal Entegrasyonunun Kuşaklar Arası Karşılaştırılması: Kültürleşme”, Bilig, 55, 103-134.

Şahin, B. (2012). “Almanya'daki Türk Göçmenlerin Sosyal Entegrasyonunun Kuşaklar Arası Karşılaştırılması: Kimlik ve Ait Hissetme”, Hacettepe Üniversitesi Türkiyat Araştırmaları Dergisi, 8, 227-251.

Şahin, V. (2013). “Halide Edip Adıvar'ın 'Yeni Turan' Romanını Yeniden Anlam(landırm) a”. Erdem Dergisi, 64, 103-122.

Şen, F. (2010). “Almanya'daki Türkler Entegrasyon ve Gettolaşma”, 30 Temmuz 2018 tarihinde çevrimiçi, http://www.konrad.org.tr/Medya\%20Mercek/13faruk.pdf

Toksöz, G. (2006). Uluslararası Emek Göçü. İstanbul: Bağlam Yayınları.

Tol, G. (2012), “Entegrasyonu Etkileyen Makro Düzey Etkenler: Almanya ve Hollanda'da Türkler”, Migration Letters, 303-310.

UNRISD. (1994). Social Integration: Approaches and Issues. UNRISD Briefing Paper No. 1, World Summit For Social Development 
Witte, N. (2018), "Responses to Stigmatisation and Boundary Making: Destigmatisation Strategies of Turks in Germany", Journal of Ethnic and Migration Studies, 44(9), 1245-1443.

Yalçın, C. (2002). “Çokkültürcülük Bağlamında Türkiye’den Batı Avrupa Ülkelerine Göç”, C. Ü. Sosyal Bilimler Dergisi, 26(1), 45-60.

Yeşilyaprak, B. (1989). "Kuşak Çatışması”, Eğitim ve Bilim, 50-53.

Yılmaz, H. (2013). "İletişim Aracı Metin ve Tipolojisi”, The Journal of Academic Social Science Studies, 6(6), 1311-1321.

Yurdakul, A. (2018), “Almanya’da Yaşayan Üçüncü Nesil Türkiye Kökenli Göçmenlerde Kimlik Algısı”, Yönetim, Ekonomi, Edebiyat, İslami ve Politik Bilimler Dergisi, 3(1), 141-163. 